\title{
ВИЗНАЧЕННЯ ВЗАЄМОДІї ПОТОКІВ ІНФОРМАЦІї ПРИ ОЦІНЦІ ЯКОСТІ ФОРМУЛЯРНОї СИСТЕМИ
}

\author{
В. Є. Бліхар \\ ДВНЗ "Тернопільський державний медичний університет ім. І. Я. Горбачевського \\ МОЗ України"
}

\begin{abstract}
Формулярна система лікарських засобів, що створена та впроваджується в Україні з 2009 р., потребує ефективного зворотного зв'язку для оцінки ї̈ дієвості [2, 4]. 3 цією метою використовується механізм моніторингу на основі визначених критеріїв якості та індикаторів, що здійснюеться на всіх рівнях функціонування формулярної системи [3]. Процес збору та подальшої автоматизованої обробки інформації потребує визначення потоків інформації для створення інформаційних технологій підтримки процесу моніторингу формулярної системи.
\end{abstract}

Ключові слова: індикатори моніторингу формулярної системи, потоки та рівні надходження інформації, оцінка якості формулярної системи.

\section{ОПРЕДЕЛЕНИЕ ВЗАИМОДЕЙСТВИЯ ПОТОКОВ ИНФОРМАЦИИ ПРИ ОЦЕНКЕ КАЧЕСТВА ФОРМУЛЯРНОЙ СИСТЕМЫ}

В. Е. Блихар

ГВУз "Тернопольский государственный медицинский университет им. И. Я. Горбачевского МЗ Украины"

\begin{abstract}
Формулярная система лекарственных средств, коротая создана и внедряется в Украине с 2009 г., требует эффективной обратной связи для оценки ее действенности [2, 4]. С этой целью используется механизм мониторинга на основе определенных критериев качества и индикаторов, осуществляющийся на всех уровнях функционирования формулярной системы [3]. Процесс сбора и последующей автоматизированной обработки информации требует определения потоков информации для создания информационных технологий поддержки процесса мониторинга формулярной системы.
\end{abstract}

Ключевые слова: индикаторы мониторинга формулярной системы, потоки и уровни поступления информации, оценка качества формулярной системы.

\section{DETERMINATION OF THE INTERACTION FLOW OF INFORMATION IN ASSESSING THE QUALITY OF FORMULARY SYSTEM}

V. Ye. Blikhar

\author{
SHEl «Ternopil State Medical University by I. Ya. Horbachevsky of MPH of Ukraine»
}

\begin{abstract}
Official system of medical products, created and implemented in Ukraine in 2009 requires effective feedback to assess its effectiveness [2, 4]. For this purpose, the monitoring mechanism based on predefined quality criteria and indicators, which takes place at all levels of functioning formulary system [3]. Collection process and subsequent automated data processing must be defined information flows for information technologies support the monitoring formulary system.
\end{abstract}

Key words: monitoring indicators of the formulary system, flow and level the flow of information, assessment of the quality of the formulary system.

Вступ. Відповідно до наказу МОЗ України від 28.10.2010 № 918 «Про затвердження Методичних рекомендацій щодо моніторингу та оцінки дієвості формулярної системи на етапі іï впровадження» в
Україні здійснюється моніторинг формулярної системи на основі структурованих блоків критеріїв та індикаторів - структури, процесу і результату (раціонального використання лікарських засобів) - на різних

\footnotetext{
(c) B. C. Бrixap
} 
рівнях управління: галузевому, регіональному, локальному. Отже, більше двадцяти запропонованих індикаторів та різні рівні їх збору потребують визначення потоків надходження інформації для подальшої обробки та оцінки.

Мета дослідження. Обгрунтування та розробка функціональної схеми взаємодії потоків інформації на трьох рівнях системи охорони здоров'я (галузевому, регіональному, локальному) для подальшої оцінки якості діяльності формулярної системи в Україні.

Матеріали і методи дослідження. Матеріалами дослідження слугували наукові джерела та галузеві нормативно-правові документи, що регулюють функціонування формулярної системи в Україні. Ви- користані методи системного аналізу та моделювання з графічним представленням моделей.

Результати та їх обговорення. Визначення індикатора безпосередньо пов'язане з його обчисленням, реєстрацією (яким чином і ким) та прийняттям рішень за результатами аналізу отриманих даних в порівнянні 3 встановленими (цільовими) даними. Цей процес потребує обов'язкового використання інформаційних технологій та залучення засобів автоматизованої обробки електронної інформації.

Індикатори структури, процесу та результату моніторингу формулярної системи за рівнем збору інформації поділяються на галузеві, регіональні та локальні (рис. 1).

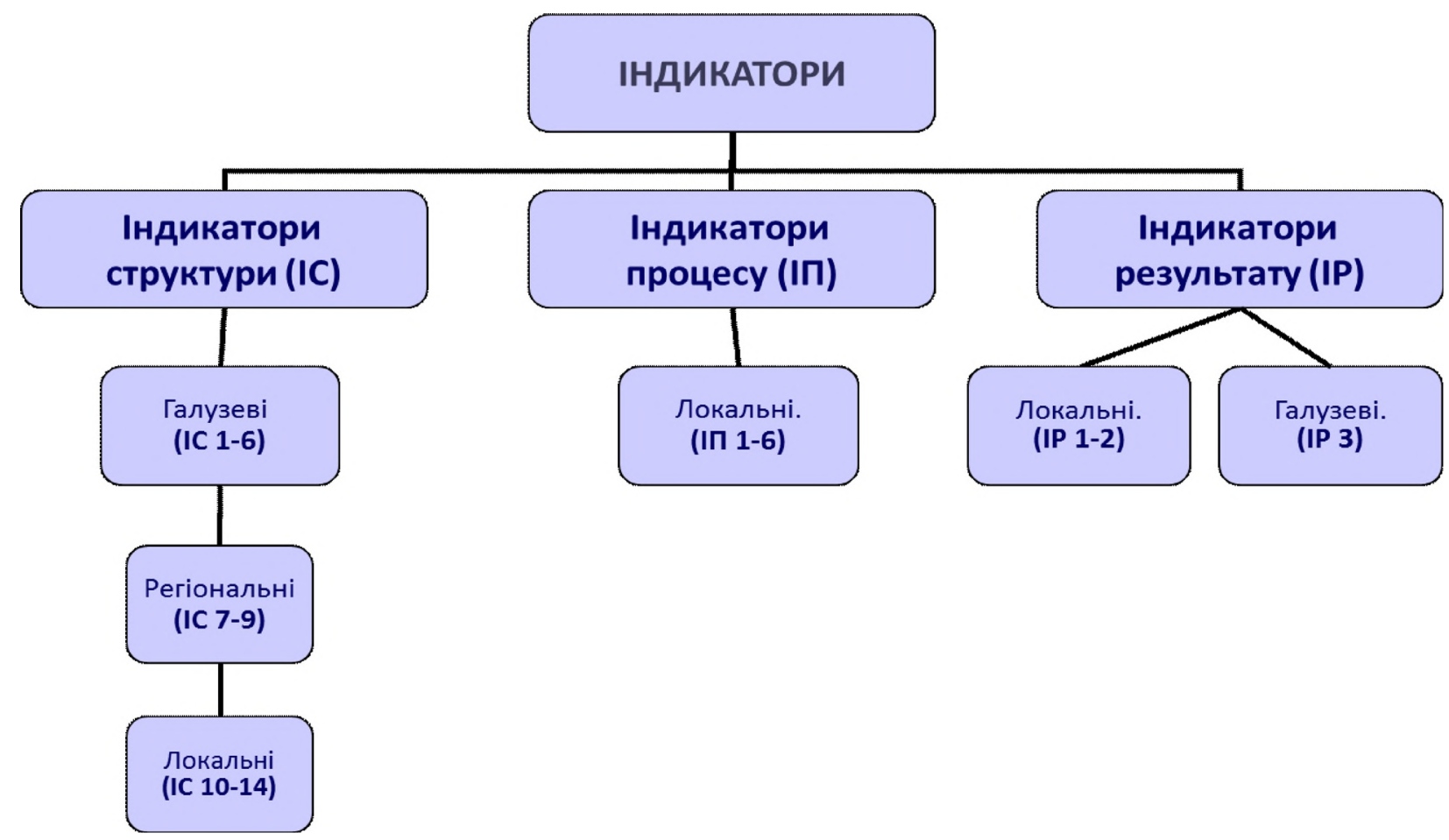

Puc. 1. Рівні збору інформації індикаторів моніторингу формулярної системи.

Система інформаційного забезпечення моніторингу формулярної системи на локальному рівні (окремий заклад охорони здоров'я) здійснюеться фармакотерапевтичною комісією(ФТК). Збір інформації про застосування лікарських засобів відбувається за всіма формулярами (локальним, регіональним, державним). Зібрана інформація застосовусться для модифікації локального формуляра. Також проводиться оцінка доступності вказаних формулярів для персоналу закладу охорони здоров'я. Отримана інформація вводиться в он-лайнові форми (за допомогою Google Forms) індикаторів моніторингу IC 10-IC14, III1-III6, IP1-IP2.
На регіональному рівні (області, АР Крим) здійснюється агрегація даних по індикаторах моніторингу IC10-IC14, IП1-IП6, IP1-IP2, що були введені на локальному рівні. При цьому застосовується технологія автоматизованого імпорту даних з Google Forms в електронні таблиці Google Spreadshet. 3ібрана інформація застосовусться для модифікації регіонального формуляра. Крім того, вказані статистичні дані направляються в ЦФК. Необхідно також зібрати дані та заповнити онлайнові форми (за допомогою Google Forms) по індикаторах IC7-IC9.

На галузевому рівні (ЦФК МО3 України, клінікоекспертні групи) здійснюється збір інформації про 
організаційно-правове забезпечення функціонування формулярної системи (індикатори моніторингу IC1IC6) та раціональне використання лікарських засобів на державному рівні (індикатор IP3). Отримана інформація вводиться в он-лайнові форми (за допомогою Google Forms) і служить основою для генерації звітної документації у форматі електронних табллиц Google Spreadshet [1]. В подальшому проводиться аналіз та інтеграція статистичних даних, зібраних в аналогічних форматах на локальному та регіональному рівнях.
Отримана інформація застосовується для модифікації державного формуляра.

Функціональна схема взаємодії потоків інформації при оцінці якості формулярної системи представлена на рисунку 2. Моніторинг формулярної системи має здійснюватись на кожному рівні управління системою (галузевому, регіональному, локальному) за визначеними індикаторами, завдяки чому можна відстежити досягнутий рівень ефективності діяльності системи і порівняти його з еталонним.

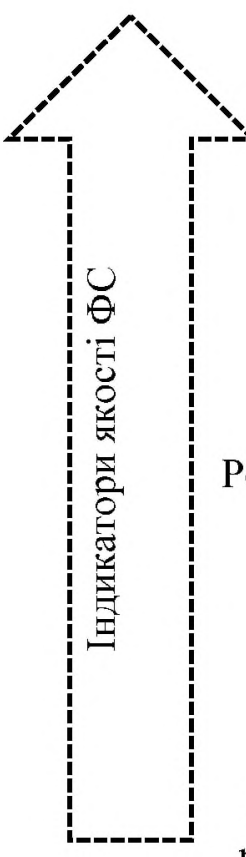

Галузевий
рівень
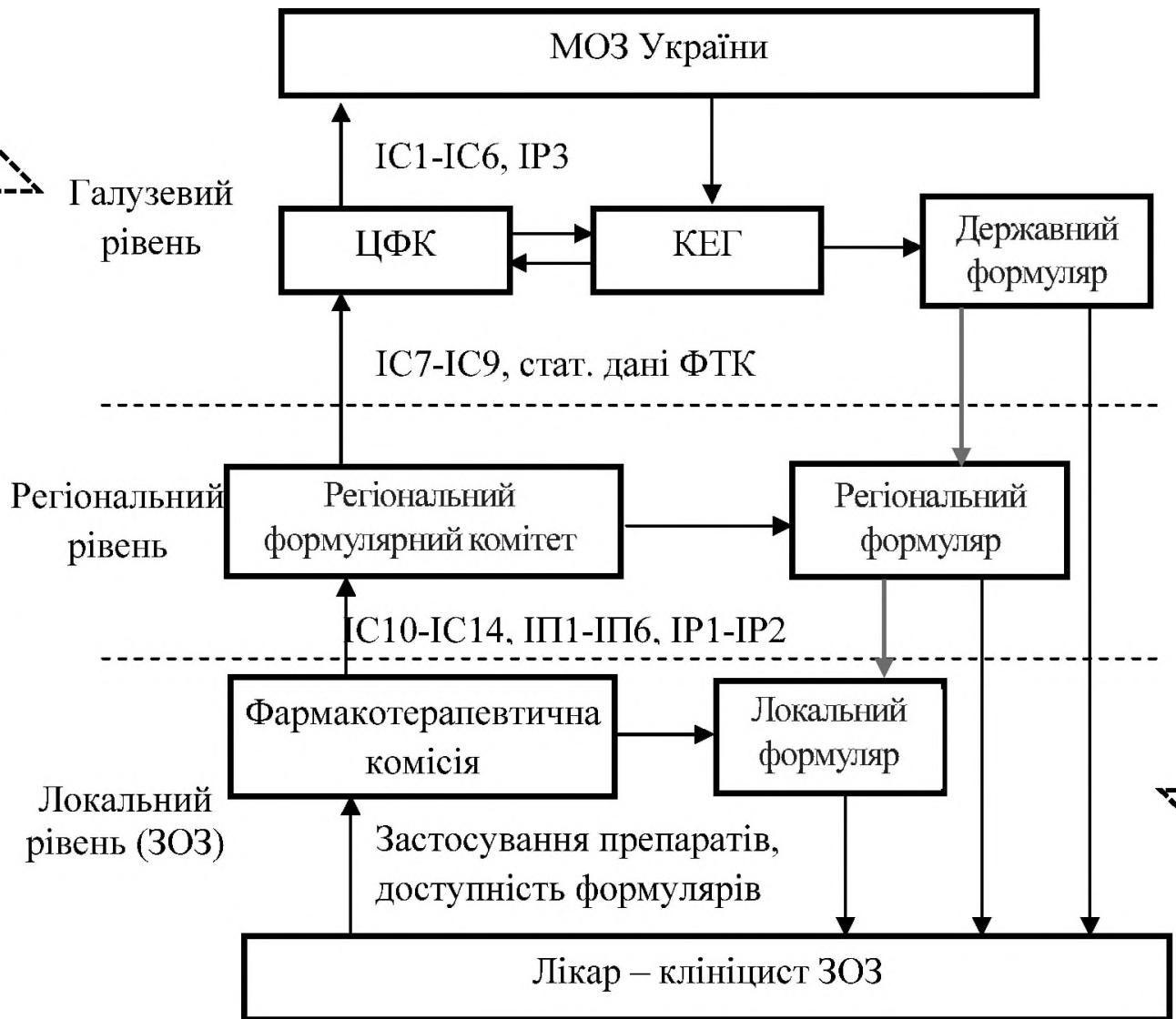

Puc. 2. Функціональна схема взаємодії потоків інформації при оцінці якості формулярної системи.

Збір даних відбувається на рівні закладів охорони здоров'я, на регіональному (АР Крим, управління охорони здоров'я) та галузевому рівнях (ЦФК МОЗ України). Інформаційні потоки йдуть по висхідній і в зворотному напрямку - від ЦФК МОЗ України (поточного випуску Державного формуляра ЛЗ) до локального формуляра закладу охорониздоров'я. Відповідно до наказу МО3 України від 28.10.2010 №918 ЦФК МОЗ України готує щорічний звіт про результати моніторингу формулярної системи лікарських засобів та піддає аналізу і оцінці ефективність діяльності цієї системи.
Висновки. 1. Обгрунтування та розробка індикаторів, за якими можна оцінити дієвість формулярної системи, потребує інформаційної підтримки, першим кроком до забезпечення якої $є$ визначення потоків надходження інформації для подальшої обробки та оцінки даних.

2. Розроблена функціональна схема взаємодії потоків інформаціїпри оцінці якості формулярної системи. Збір даних відбувається на рівні закладів охорони здоров'я, на регіональному (АР Крим, управління охорони здоров'я) та галузевому рівнях (ЦФК МОЗ України). Інформаційні потоки йдуть по висхідній і в 
зворотному напрямку - від ЦФК МОЗ України (поточного випуску Державного формуляра Л3) до локального формуляра закладу охорони здоров'я.

\section{Лiтература}

1. Марценок В. П. Конщептуальные подходы к интегрированной среде проведения научных медико-биологических исследований/В.П.Марценюк, А. В. Семенец, А. С. Сверстюк // Штучний інтелект. - 2003. - № 2. - С. $35-43$.

2. Про затвердження Конщепції розвитку фармацевтичного сектора галузі охорони здоров'я України / Міністерство охорони здоров'я України. - Офіц. вид. - К., 2007. - 838. (Нормативний документ МО3 України. Наказ).
3. Про затвердження Методичних рекомендацій щодо моніторингу та оцінки дієвості формулярної системи на етапі іiі впровадження / МОЗ України - Офіц. вид. -2010. -918. (Нормативний документ МO3 України. Наказ).

4. Про створення формулярної системи забезпечення лікарськими засобами закладів охорони здоров'я. Наказ МО3 України від 22.07.2009 р. № 529. [Електроннийресурс]. - Режим доступу : http://www.moz.gov.ua/ua/portal/ dn 20090722 529.html. 